ISCKMC 2020

International Scientific Congress «KNOWLEDGE, MAN AND CIVILIZATION»

\title{
DEVELOPMENT OF A COMPREHENSIVE METHOD FOR ASSESSING INVESTMENT ACTIVITIES OF INSURANCE COMPANIES
}

\author{
Irina Petrovna Hominich (a)*, Oksana Vladimirovna Savvina (b), \\ Natalia Fedorovna Cheluhina (c), Elmira Ahmetshaevna Asyaeva (d) \\ *Corresponding author
}

(a) Plekhanov Russian University of Economics, 36, Stremyanny Lane, Moscow, 117997, Russia, 9204977@mail.ru,

(b) Plekhanov Russian University of Economics, 36, Stremyanny Lane, Moscow, 117997, Russia, Savvina.OV@rea.ru,

(c) Plekhanov Russian University of Economics, 36, Stremyanny Lane, Moscow, 117997, Russia, Tchelukhina.NF@rea.ru,

(d) Plekhanov Russian University of Economics, 36, Stremyanny Lane, Moscow, 117997, Russia, Mira13031987@mail.ru

\begin{abstract}
In the conditions of modern economic development, the effective implementation of investment activities, including those performed by insurance companies, is a factor determining economic growth and contributing to the improvement of welfare of the state and the population. The need and prerequisites for investment activities of insurance companies stem from their specific features. The process of providing insurance services is different from other types of entrepreneurship. This is due to the fact that the policyholder advances the insurer, and insurance services are provided after a long time or may not be provided at all. The insurer has free funds, which should be invested in order to generate additional income. Investment activities of the insurer must be regulated by the government, since the policyholders are deprived of the opportunity to control the process of disposing funds provided to the insurance organizations, which may threaten the fulfillment of obligations under insurance contracts. Thus, the goal of state regulation is to minimize the risk of investment due to the secondary nature of the investment portfolio in relation to the insurance portfolio. Investment activities of an insurance company is phased activities of an insurer acting as an investor.
\end{abstract}

2357-1330 @ 2021 Published by EuropeanPublisher.

Keywords: Investment activity, assessment methods, efficiency, management quality 


\section{Introduction}

Assessing investment activities of an insurance company is useful for the insurer and external users. When analyzing the theoretical provisions of investment assessment, it was revealed that the target audience of the investment analysis can be company owners, counterparties, creditors, and the government. We assume that the assessment of investment activities of the insurance company can be carried out by the insured party, that is, the client of this company. This is especially true for people who want to take out life insurance. The buyer of any service wants to be sure of its quality and compliance with own expectations. Therefore, it is important to treat the choice of an insurance company with due rationalism. You can rely on the assessment of performance of the insurance company by expert agencies, financial statements, or do it yourself. It is necessary to assess the financial position of an insurance company and its investment activities. Insurance reserves include contributions of the insured, which will be invested in assets. An incorrect investment policy can deteriorate the position of an insurance company in the market, its financial performance, and lead to license revocation and bankruptcy. An assessment of investment activities of the insurer will help determine its investment strategy, conscientiousness in meeting legal requirements, etc. If no factors that contradict expectations of a potential client are identified, a decision in favor of this company can be made. One should not ignore external factors, the unstable state of the Russian economy. Thus, another principle for developing a method for evaluating investment activities is its practical significance for the insurance company, and a possibility of partial application by ordinary users.

\section{Problem Statement}

Insurance companies are financial institutions aimed to perform insurance activities by protecting interests of individuals and legal entities, the Russian Federation, its regions and municipalities in case of insured events at the expense of monetary funds generated from insurance premiums and other funds (Druva, 2017). The role of insurance companies is not limited to the compensation for losses. In modern conditions, the funds of insurance organizations are used for accumulation and investment. Thus, in addition to insurance activities, insurers perform investment ones.

The need and prerequisites for investment activities stem from their specific features. The process of providing insurance services is fundamentally different from other types of entrepreneurship. The policyholder advances the insurer; insurance services are provided after a long time or may not be provided at all. The insurer has free funds, which should be invested in order to generate additional income. Investment activities of the insurer must be regulated by the government, since the policyholders are deprived of the opportunity to control the process of disposing funds, which may threaten the fulfillment of obligations under insurance contracts.

Currently, there is no comprehensive method for assessing investment activities of insurance companies, which would cover all stages of the investment process and all assessment areas. 


\section{Research Questions}

The subject of research is theoretical and methodological foundations for assessing investment activities of insurance companies in the Russian Federation.

The subject is determined by the weak development of special methods for assessing investment activities of Russian insurance companies. Currently, insurance companies are full-fledged elements of the investment market. Insurance reserves are the most important internal sources of investment, and competent investment management is the key to financial stability and profitability of the insurance companies (Dubik, 2013). Due attention has not been paid to the analysis and development of methods for evaluating investment activities of insurers.

In developed countries, insurance companies have accumulated experience in conducting insurance operations and performing investment activities. Their experience testifies to the high importance of insurers as institutional investors, providing an inflow of investment resources into the real sector of the economy.

In developed countries, the market mechanism initially formed the basic principles of investment activities of insurers; then they were generalized, systematized and optimized and reflected in the legislation.

\section{Purpose of the Study}

The purpose is to study theoretical, methodological and practical aspects of assessing investment activities of insurance companies and develop a comprehensive method for its assessment.

\section{Research Methods}

The scientific methods applied made it possible to realize the conceptual unity of the research. They are a semantic analysis, a scientific generalization and a graphic presentation.

\section{Findings}

It is necessary to emphasize the existence of strict state regulation in the field of investment activities, namely:

1. The following requirements to the insurance companies: to ensure the return on investment; to ensure profitability of investment; to ensure the liquidity of assets; to form a diversified portfolio of assets.

2. To develop instructions, a list of assets for investment of insurance reserves, a procedure for their investment by setting a maximum permitted percentage.

In order to ensure license safety, the insurance company must follow legal rules and regulations. In addition, being guided by these principles and requirements, the insurer should ensure stability and profitability of the investment portfolio. 
Thus, the authors propose a method for establishing compliance with the basic requirements and standards of investment activities of an insurance company. This method will be one component of a comprehensive methodology for evaluating investment activities. According to this assessment method, the structure of assets of the insurance company and the amount of insurance reserves are established (Dorofeeva, 2017; Kim, 2016):

$$
d=\frac{a_{i}}{R_{s}},
$$

where $a_{i}$ - the cost of the $i$-th asset; $R_{s}$ is the size of insurance reserves; $d$ is a relative indicator to be compared with the standard value of the maximum permitted percentage. A similar procedure for investing in the assets of the insurer's own funds.

When determining compliance with the principle of profitability, one can calculate the rate of return on investment:

$$
R O I=\frac{\text { Investment profit }}{\text { Assets invested }}
$$

When determining the return on investments, their liquidity and diversification of the investment portfolio, it is necessary to analyze the structure of assets for reliable financial instruments, liquid assets and a variety of options for financial investments. To do this, you need to conduct a vertical analysis of assets and assess the availability of instruments with a minimal risk, the availability of assets that can quickly turn into liquid funds, and analyze the number of investment instruments in shares, their importance in the investment portfolio. The result of this analysis is the establishment of compliance or non-compliance of investment activities with the requirements and standards developed by the government. The advantage is simplicity of the analysis and direct identification of the legality of activities as the starting point for the company's license. The disadvantages are a superficial assessment of the principles of investment activities, and subjective conclusions.

The company can assess the investment activities. To do this, it can carry out a horizontal analysis of indicators for several periods: the volume of its investment portfolio, results of investment activities, insurance premiums, insurance reserves and payments. With an increase in the volume of insurance premiums and insurance reserves and a decrease or unchanged indicators of insurance payments, investment increases and the scale of investment activities grows.

Another method for assessing investment activities is indirect. It involves the assessment of a financial position of the insurance company "before" and "after" investment activities (Bisultanova, 2018; Magomadova, 2019; Okorokova, 2016). Investment problems can affect the solvency and financial stability of the insurance company. Therefore, it is advisable to calculate the following indicators:

- the ratio of insurance reserves to assets. The greater the numerical value of the coefficient and its growth in dynamics, the higher the financial stability of the insurer.

- the ratio of equity to liabilities. It is important to have a numerical value of this ratio over 1.0. The higher the value of the indicator, the higher the degree of solvency.

- availability of own circulating assets. It is calculated as the difference between current assets and short-term liabilities and assessed over time (an increase indicates the development of company's activities). 
Thus, if after the beginning of investment activities, the indicators of financial stability and solvency have worsened and there are no external factors affecting the activities of the insurance company, it is quite possible that this is the influence of incorrect investment activities.

The methods for assessing investment activities of insurance companies proposed by the authors were analyzed as simplified assessment options available for any user. Arrange all the methods for assessing investment activities by time and depth of the analysis. This will be the result of the development of a comprehensive method for assessing investment activities of insurance companies (Bespalov \& Bespalova, 2014; Bisultanova, 2019).

The comprehensive method for analyzing investment activities of insurance companies (Dorofeeva, 2017):

Stage 1. Evaluation of the effectiveness of investment projects in accordance with the Methodological Recommendations. It should be carried out at the initial stage of investment activities when choosing an investment object. It can also be used throughout the entire investment process to adjust investment activities.

Stage 2. Assessment of investment activities in terms of their legality. It is carried out at the initial stages of investment activities when creating a portfolio from selected investment instruments. It ensures compliance with established requirements and regulations.

Stage 3. Evaluation of the effectiveness of investment activities (the methodology by Bespalov \& Bespalova, 2014). It implies a general analysis of investment activities based on the ratios and integral indicators. It is carried out in carrying out investment activities to search for problem areas of investment in the portfolio structure.

Stage 4. Assessment of quality of investment management (the methodology by of V.V. Frolova). It involves the express diagnostics based on a system of coefficients and use of an integral quality indicator. It is carried out when problems arise.

Stage 5. Evaluation of the effectiveness of investment activities (the methodology by Minakov A.V.). It is carried out directly during investment activities and includes a multidisciplinary analysis of investment activities, i.e. it is carried out according to several parameters: the efficiency of portfolio management, the return on investment of the insurer, the assessment of the investment portfolio, the assessment of financial indicators, depending on the results of investment activities. It can be divided into individual assessment methods if it is necessary to study one parameter. In general, it is suitable for a deep, thorough analysis of key indicators of investment performance.

Stage 6. Assessment of the development of investment activities. It can be used as an additional measure in the aggregate assessment. It is carried out to obtain data on the progress or regression of investment performance indicators.

Stage 7. An indirect assessment of investment activities, which involves the projecting of the dynamics of financial indicators of the insurance company. It is carried out before and after the start of investment activities to track correlated changes. 


\section{Conclusion}

On the basis of the investment analysis and available special methods for evaluating investment activities, a comprehensive method for evaluating investment activities of insurance companies has been developed. It is subdivided into stages and evaluates investment activities. It involves the assessment of the effectiveness of investment projects, legality, efficiency of investment areas, quality assessment, multidisciplinary assessment, development assessment and indirect assessment. This method should take into account and exclude all possible risks, since it covers various valuation areas and involves the indepth analysis and monitoring of investment activities. Using this method for assessing investment activities, an insurance company can draw conclusions about quality and further directions of the investment policy and develop mechanisms to optimize the investment portfolio. The next step is to test this methodology.

\section{References}

Bespalov, R. A., \& Bespalova, O. V. (2014). Methods for analyzing the effectiveness of innovations and investments in insurance Bull. of Bryansk State Univer., 3, 9.

Bisultanova, A. A. (2018). Modern trends in corporate finance management Espacios: Sociacion de Profesionales y Tecnicos del CONICIT, 39(31).

Bisultanova, A. A. (2019). Assessment of interregional differences in the socio-economic development of the subjects of the southern federal district. Terra Econ., 7(4-2), 281.

Dorofeeva, Yu. V. (2017). Features of legal regulation of investment activities of insurance companies. Interactive sci., 15, 104.

Druva, A. E. (2017). Problems of financial resources management of an insurance company. Bull. of youth sci., 4, 3.

Dubik, E. A. (2013). Evaluation of the effectiveness of investment activities in economic systems at different levels of management. Vest. of ChelSU. Econ., 40, 32.

Kim, A. D. (2016). The main factors and criteria affecting the financial stability of a commercial bank. Sci. discussion: issues of econ. and manag., 2(46), 176.

Magomadova, M. M. (2019). Russian banking system in economic and social development of the country. The European Proceedings of Social \& Behavioural Sciences EpSBS, SCTCGM 2018, 1000-1006.

Okorokova, O. A. (2016). Modern aspects of investment activity in insurance companies. Innovat. Sci., $14,96$. 